Ann. rheum. Dis. (1955), 14, 288.

\title{
STUDIES OF THE ACID POLYSACCHARIDE OF THE WHITE CELLS IN RHEUMATIC AND OTHER DISEASES SHOWING ITS SIMILARITY TO THE ACID POLYSACCHARIDE OF AMYLOID
}

\author{
BY
}

\author{
M. BASSIOUNI \\ From the Special Unit for Juvenile Rheumatism, Canadian Red Cross Memorial Hospital, Taplow, \\ near Maidenhead, Berks
}

(RECEIVED FOR PUBLICATION MARCH 25, 1955)

In a previous investigation (Bassiouni, 1954) injected heparin was isolated from human blood and tissues and endogenous acid polysaccharides from various tissues. The method is summarized in Fig. 1. The isolated acid polysaccharides (A.P.S.) were estimated in terms of beef heparin biologically by their anticoagulant activity and colorimetrically by their dye-binding capacity. The ratio between the anticoagulant activity in units and the colorimetric value in $\mathrm{mg}$. (A/C ratio) characterized the A.P.S. as heparin-like or chondroitin sulphate-like, since in the latter the $\mathrm{A} / \mathrm{C}$ ratio was very low (between 0-4) compared with 100 for the beef heparin. Paper electrophoresis of the isolated extracts was useful as a confirmatory procedure, since different mobilities were shown by beef heparin, human heparin, and human chondroitin sulphate obtained from cartilage. When $420 \mathrm{ml}$.samples of normal human blood were extracted by the same procedure it was found that the plasma was free from the heparin-like substance found in tissues, but that it contained traces of two other acid polysaccharides detected by paper electrophoresis: one moving at the same rate as the chondroitin sulphate of cartilage and another with a lower mobility (Fig. 2, opposite). The normal white cells contained acid polysaccharides (A.P.S.) amounting to $80 \mu \mathrm{g}$./ $420 \mathrm{ml}$. blood with an $\mathrm{A} / \mathrm{C}$ ratio of 10 , and it was thought to be mainly a chondroitin sulphate-like A.P.S. This A.P.S. could not be detected in most of the normal 4-ml. blood samples that were extracted.

However, when 4-ml. blood samples from rheumatic fever patients were extracted by the same procedure, it was observed during step $F$ of the isolation that the crude precipitate obtained, which is dark bluish in normal blood, included another fine precipitate of a metachromatic reddish-violet

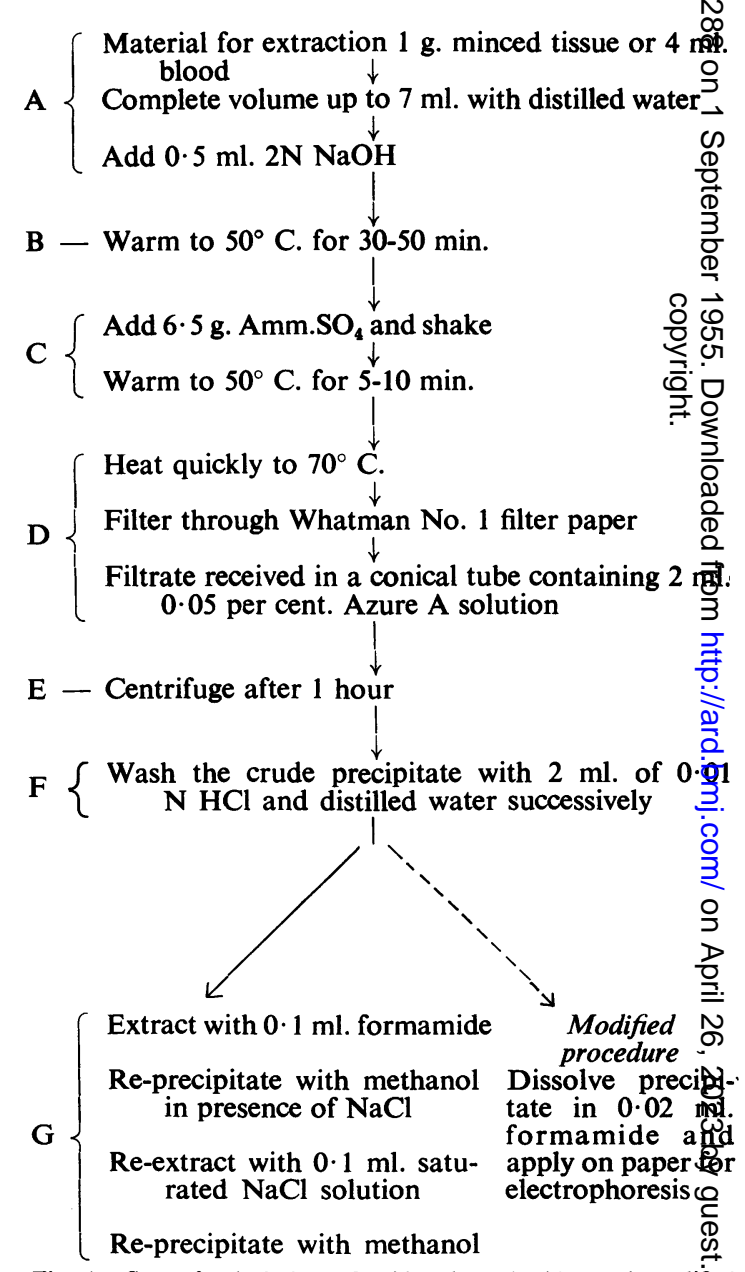

Fig. 1.-Steps for isolation of acid polysaccharides and modififd procedure for micro-analysis using filter-paper electrophoresis 


\section{Results}

Extracts from 4-ml. blood samples showed an A.P.S. of this kind in eight out of eleven cases of rheumatic fever, a faint trace in one, and none in two (Table I). A case of "pure" chorea (without rheumatic activity) was negative, but one chorea together with fever gave a faint trace. Four cases of rheumatoid arthritis all gave positive results. Of five samples of normal blood used as controls, four gave negative results, but in one there was a faint trace of A.P.S.

TABLE I

ISOLATION OF AN ACID POLYSACCHARIDE FROM THE BLOOD OF RHEUMATIC PATIENTS AND CONTROLS

\begin{tabular}{|c|c|c|c|c|c|}
\hline Diagnosis & $\begin{array}{l}\text { Case } \\
\text { No. }\end{array}$ & Sex & Age & $\begin{array}{c}\text { Sedi- } \\
\text { men- } \\
\text { tation } \\
\text { Rate }\end{array}$ & $\begin{array}{c}\text { Acid Poly- } \\
\text { saccharides } \\
\text { detected on Paper } \\
\text { Electrophoresis } \\
\text { from } 4 \mathrm{ml} \text {. Blood }\end{array}$ \\
\hline $\begin{array}{c}\text { Rheumatic } \\
\text { Fever }\end{array}$ & \begin{tabular}{|r}
1 \\
$\mathrm{C} 2$ \\
3 \\
4 \\
5 \\
6 \\
7 \\
$\mathrm{C}$ \\
9 \\
$\mathrm{C} 10$ \\
11
\end{tabular} & $\begin{array}{l}F \\
F \\
F \\
F \\
F \\
F \\
F \\
F \\
F \\
F \\
F\end{array}$ & $\begin{array}{l}12 \\
13 \\
13 \\
13 \\
16 \\
15 \\
12 \\
17 \\
28 \\
15 \\
16\end{array}$ & $\begin{array}{r}7 \\
20 \\
5 \\
44 \\
7 \\
22 \\
8 \\
15 \\
87 \\
23 \\
10\end{array}$ & $\begin{array}{c}t++ \\
+++ \\
+++ \\
+++ \\
+++ \\
+++ \\
+++ \\
++ \\
+ \\
-\end{array}$ \\
\hline $\begin{array}{l}\text { Rheumatoid } \\
\text { Arthritis }\end{array}$ & $\begin{array}{r}12 \\
13 \\
14 \\
15\end{array}$ & $\begin{array}{l}\mathbf{F} \\
\mathbf{F} \\
\mathbf{M} \\
\mathbf{F}\end{array}$ & $\begin{array}{l}15 \\
14 \\
40 \\
16\end{array}$ & $\begin{array}{l}11 \\
10 \\
44 \\
31\end{array}$ & $\begin{array}{l}t+t \\
+t+ \\
+t- \\
+t+\end{array}$ \\
\hline $\begin{array}{l}\text { Pure Chorea } \\
\text { with Fever }\end{array}$ & $\begin{array}{l}16 \\
17\end{array}$ & F & $\begin{array}{l}15 \\
13\end{array}$ & $\begin{array}{r}5 \\
11\end{array}$ & + \\
\hline Normals & $\begin{array}{l}18 \\
19 \\
20 \\
21 \\
22\end{array}$ & $\begin{array}{l}F \\
F \\
F \\
F \\
M\end{array}$ & $\begin{array}{l}28 \\
19 \\
19 \\
22 \\
38\end{array}$ & $\begin{array}{l}- \\
z \\
-\end{array}$ & $\begin{array}{l}- \\
\overline{-} \\
- \\
-\end{array}$ \\
\hline
\end{tabular}

In other diseaśes investigated (Table II, overleaf), the most remarkable A.P.S. band was shown in samples of long-standing diabetes, asthma, and acute nephritis; it was also present to the same extent as in rheumatic diseases in other conditions (Fig. 3, overleaf).

Identification of A.P.S.-To identify this A.P.S., $80 \mathrm{ml}$. blood were collected from patients with rheumatic fever and rheumatoid arthritis. The white cells and plasma were extracted separately, using the full procedure previously described (Bassiouni, 1954). The result shows that the A.P.S. of the white cells from $80 \mathrm{ml}$. blood gave a value of $38 \mu \mathrm{g}$. in terms of beef heparin (colorimetric) and an anticoagulant activity of 1.4 units, thus having an $\mathrm{A} / \mathrm{C}$ ratio of 37. An A.P.S. was obtained from the plasma of $80 \mathrm{ml}$. blood which had a

* The basic dye Azure A used gives a bluish violet precipitate with chondroitin sulphate and hvaluronic acid, but a metachromatic precipitate (reddish-violet) with beef heparin-unpublished data. 

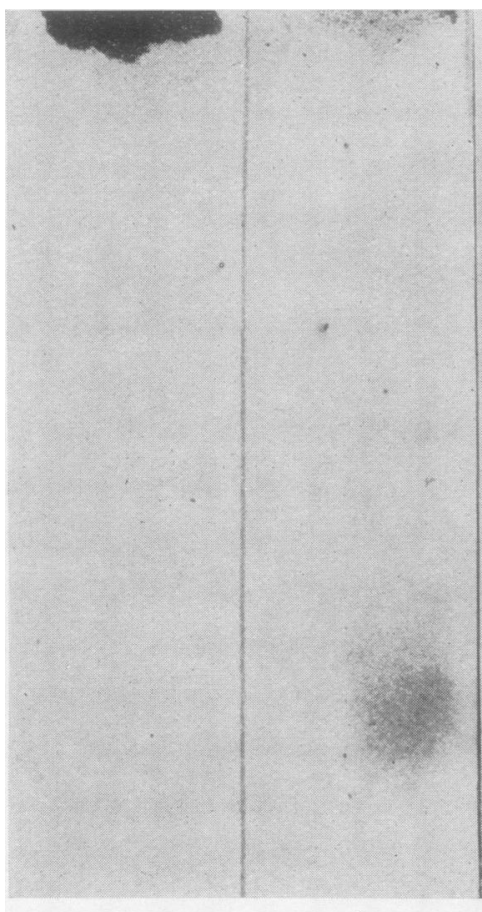

Fig. 3.-Paper electrophoresis of acid polysaccharide isolated from $4 \mathrm{ml}$. blood from:

(a) stone ureter (negative), (b) diabetes, (c) carditis (rheumatic fever), (d) acute nephritis, $(e)$ pleural effusion, $(f)$ asthmace

TABLE II

ISOI.ATION OF AN ACID POLYSACCHARIDE FROM 4-ML. BLOOD SAMPLES FROM PATIENTS WITH VARIOUS DISEASES

\begin{tabular}{|c|c|c|c|c|c|}
\hline \multicolumn{3}{|c|}{ Diagnosis } & \multirow{2}{*}{$\frac{\text { Sex }}{M}$} & \multirow{2}{*}{$\frac{\text { Age }}{53}$} & \multirow{2}{*}{$\frac{\text { A.P.S. }}{-}$} \\
\hline Stone left kidney & . & . & & & \\
\hline Hypertension & . & . & $\mathbf{M}$ & 63 & + \\
\hline Duodenal ulcer & . & . . & $\mathbf{M}$ & 17 & $T$ \\
\hline Asthma & . & . & $\begin{array}{l}\mathbf{M} \\
\mathbf{M}\end{array}$ & $\begin{array}{l}44 \\
56\end{array}$ & $+1+$ \\
\hline Coronary thromb & sis & . & $\begin{array}{l}\mathrm{M} \\
\mathrm{F}\end{array}$ & $\begin{array}{l}50 \\
77\end{array}$ & + \\
\hline Diabetes & . & . & $\begin{array}{l}M \\
M\end{array}$ & $\begin{array}{l}55 \\
62\end{array}$ & $+\div$ \\
\hline Pleural effusion & . & . & $\begin{array}{l}\mathrm{M} \\
\mathrm{F}\end{array}$ & $\begin{array}{l}12 \\
27\end{array}$ & - \\
\hline Acute nephritis & $\ldots$ & . & $\mathrm{F}$ & 13 & ++ \\
\hline Mitral stenosis & . & . & $\mathrm{F}$ & 50 & $\because-$ \\
\hline ? Cerebral aneury & & . & $\mathrm{F}^{*}$ & 38 & $\cdots$ \\
\hline Bronchiectasis & $\ldots$ & . & $F$ & 28 & - \\
\hline Pulmonary tuberc & losis & - & & & 4 positive \\
\hline
\end{tabular}

* Blood sample 2 ml. only.

colour value of $20 \mu \mathrm{g}$. Another extraction of the plasma and white blood cells (separately) from $40 \mathrm{ml}$. blood from patients with rheumatic fever only was carried out, and the isolated A.P.S. was run b paper electrophoresis (Fig. 4). The plasma ban

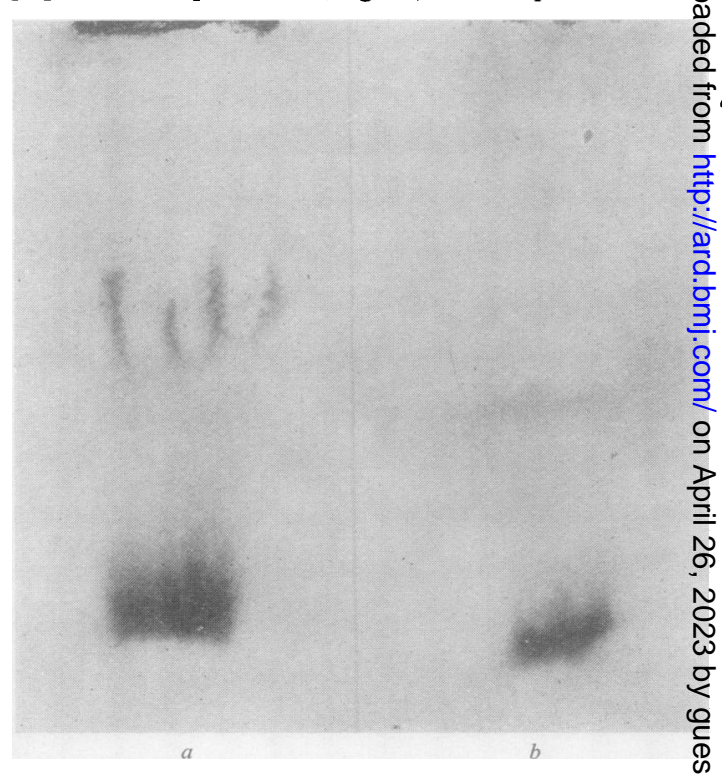

Fig. 4.- Paper electrophoresis of acid polysaccharide extracted from $45 \mathrm{ml}$. blood collected from patients with acute rheumatic fevero (a) from white cells, (b) from plasma. 
was only one-third as dense as that of the white cells. This white-cell A.P.S. had a mobility on filter paper greater than chondroitin sulphate of cartilage, but less than that of beef heparin (Fig. 5). It formed a metachromatic precipitate with the Azure A dye and colour of the compound had a maximum absorption at $580 \mu \mathrm{g}$.

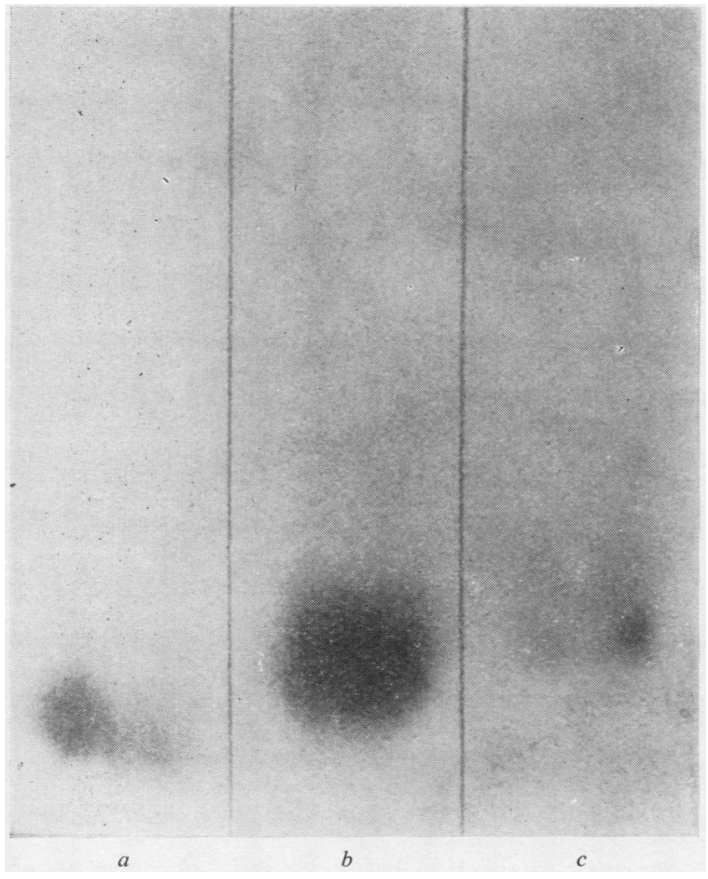

Fig. 5.-Paper electrophoresis of:

(a) beef heparin

(b) white cell A.P.S.,

(c) chondroitin sulphate (human cartilage)

An amyloid liver from a long-standing case of rheumatoid arthritis extracted by the usual procedure gave $0.5 \mathrm{mg}$. A.P.S./g. fresh liver compared with $0.07 \mathrm{mg} . / \mathrm{g}$. in normal liver (about seven times the normal content). It had an $\mathrm{A} / \mathrm{C}$ ratio of 24 and its compound with Azure A had a very metachromatic colour with a maximum spectral absorption at $580 \mu \mathrm{g}$. (Fig. 6). These A.P.S. from amyloid liver and from white blood cells resemble heparin more than chondroitin sulphate or hyaluronic acid, since the latter substances have a negligible anticoagulant activity and their compounds with Azure A after being washed with $\mathrm{N} / 100 \mathrm{HCl}$ and then re-suspended in distilled water are not metachromatic and have a maximal spectral absorption at $620 \mu \mathrm{g}$. Moreover, the A.P.S. of the white cells, as well as the amyloid A.P.S. (Fig. 7, overleaf), has a greater mobility than chondroitin sulphate, and it
$\mathrm{O}-\mathrm{O}=$ Amyloid A.P.S.

$\mathrm{X}-\mathrm{X}=$ Chondroitin sulphate (human cartilage)

- $=$ White cell A.P.S.(s)
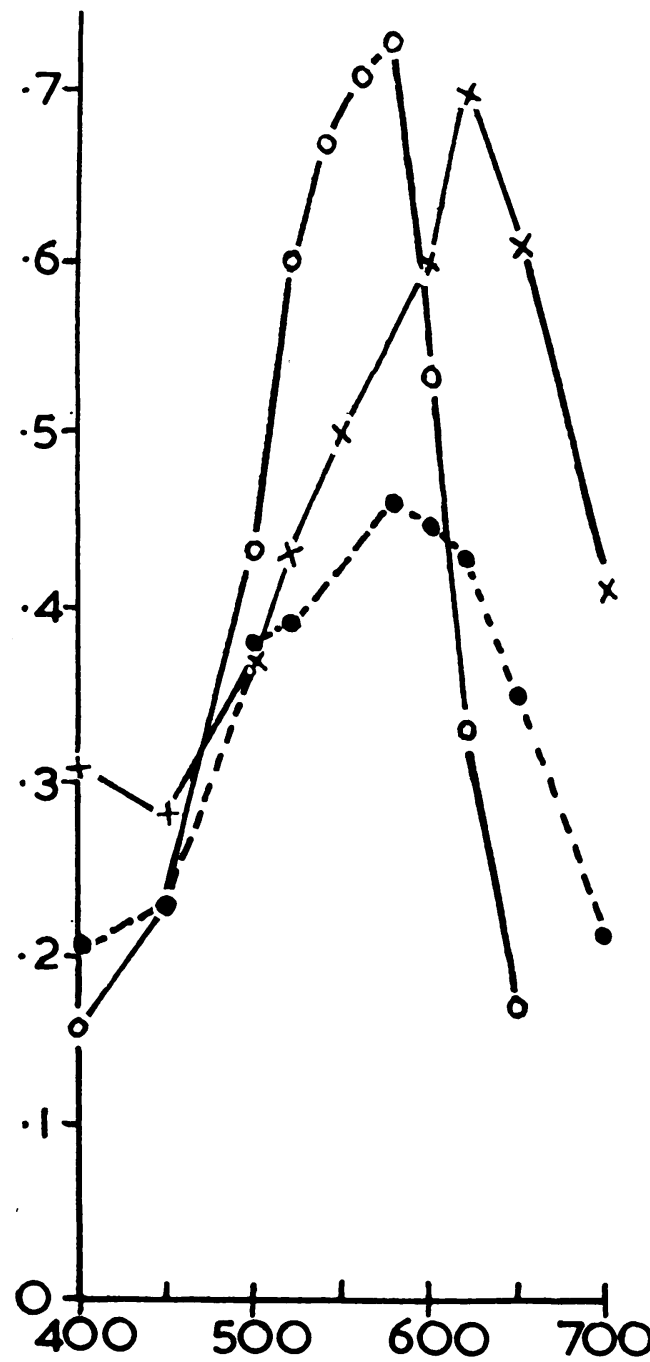

$\mu g$.

Fig. 6.-Absorption curves of Azure A complexes with amyloid A.P.S., chondroitin sulphate (human cartilage), and white cell A.P.S.(s). In each experiment the dye-acid polysaccharide complex was washed successively with $2 \mathrm{ml} . \frac{\mathrm{N}}{100} \mathrm{HCl}$ twice and with $2 \mathrm{ml}$. distilled water once; it was then re-suspended in $4 \mathrm{ml}$. distilled water. A Unicam photo-electric spectrophotometer was used with absorption vessels of $1 \mathrm{~cm}$. depth and $4 \mathrm{ml}$. capacity; the latter were calibrated before being used.

must be emphasized that such difference in mobility between the various A.P.S. becomes apparent when they are run for 2 hours, using a potential gradient $10 \mathrm{~V} / \mathrm{cm}$. Hass (1942) found in his studies of amyloid material that the isolated A.P.S. showed variations 


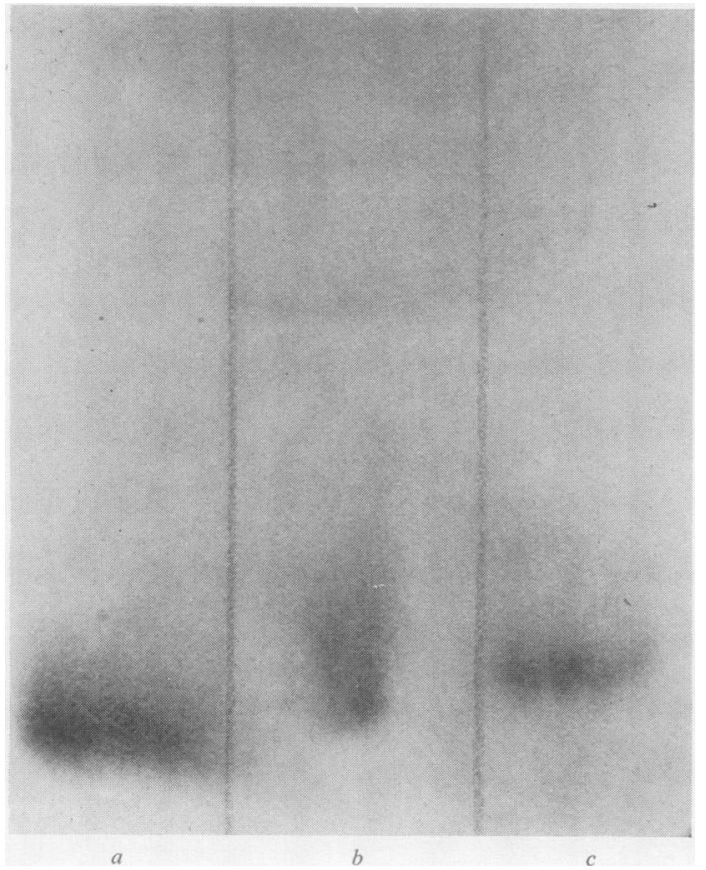

Fig. 7.-Paper electrophoresis of:

(a) beef heparin

(b) amyloid A.P.S.,

(c) chondroitin sulphate (human cartilage).

among different samples of nitrogen and sulphur content. However, he suggested that from these results the A.P.S. was probably chondroitin sulphate, but in the procedure he used for isolating the A.P.S., heparin would be lost in the barium precipitate discarded during the process of purification.

\section{Summary}

(1) An acid polysaccharide (A.P.S.) was isolated and identified on paper electrophoresis from $4 \mathrm{ml}$. blood in cases of acute rheumatic fever and rheumatoid arthritis. It was also detectable in a variety of other diseases and particularly noticeable in a longstanding case of diabetes. It was not present in appreciable amounts in normal blood.

(2) The isolated A.P.S. was found to be mainly derived from the white cells. It has a distinct anticoagulant activity compared with its colorimetric value thus having an $\mathrm{A} / \mathrm{C}$ ratio of 40 . The corresponding values for beef heparin and chondroitin sulphate are 100 and $0-4$ respectively. It has an electrophoretic motility on filter paper higher than that of chondroitin sulphate; its complex with Azure A has a metachromatic colour having a maximum absorption at $580 \mu \mathrm{g}$. This suggests that this A.P.S. is mainly of a heparin-like nature.
(3) The A.P.S. isolated from an amyloid liver of a long-standing case of rheumatoid arthritis showe similarities to that isolated from the white cells.

I wish to thank Dr. E. G. L. Bywaters for advice an help, and the Empire Rheumatism Council for a grant. $\stackrel{9}{+}$

REFERENCES

Bassiouni, M. (1954). J. clin. Path., 7, 330.
Grassmann, W., Hannig, K., and Knedel, M. (1951). Dtsch. med

Grassmann, W

Hass, G. (1942) Arch. Path. (Chicago), 34, 92.

Etude d'un polysaccharide acide des globules blanes dans. la maladie rhumatismale et dans d'autres maladies? montrant sa similarité au polysaccharide acide de lä dégénérescence amyloïde

RÉSUMÉ

(1) Un polysaccharide acide (A.P.S.) fut isolé identifié au moyen de l'électrophorèse sur papier वे filtre de 4 c.c. de sang provenant de cas de rhumatism articulaire aigu et d'arthrite rhumatismale. On le décéla aussi dans un certain nombre d'autres maladiess et sa présence fut particulièrement marquée dans un caş de vieux diabète. Dans le sang normal on n'en trouva pas de quantités appréciables.

(2) On trouva que l'A.P.S. isolé provenait surtout dess globules blancs. Il est doué d'une action anticoagulante définie en comparaison avec sa valeur colorimetrique, le raison $\mathrm{A} / \mathrm{C}$ étant 40 . Les chiffres correspondant pou l'héparine de boeuf et le sulfate de chondroïtine son respectivement 100 et $0-4$. Sa mobilité électrophorétique sur papier à filtre est supérieure à celle du sulfatểd chondroïtine; son complexe avec Azure A a une coufour métachromatique avec un maximum d'absorption. $580 \mu \mathrm{g}$. Ces résultats suggèrent que l'A.P.S. est surêin une substance dans le genre d'héparine.

(3) L'A.P.S. isolé du foie amyloïde d'un cas d'arthrites rhumatismale ancienne ressemblait à celui provenan de globules blancs.

Estudio de un polisacarido de los glóbulos blancos en $1 \mathfrak{a}$ enfermedad reumática y en otras enfermedades, mostrandळ̄ su similaridad al polisacarido ácido de la degeneración amiloidea

\section{SUMARIO}

(1) Un polisacarido ácido (A.P.S.) fué aislado identificado por medio de electroforesis sobre papel de़s filtrar de 4 c.c. de sangre procediendo de casos de reumatismo poliarticular agudo y de artritis reumatoide. Se le encontró también en algunas otras enfermedades y s(h.) presencia fué particularmente marcada en un caso de antigua diabetes. No hubo cantidades apreciables ep la sangre normal.

(2) Se vió que el A.P.S. aislado procedió ante todơ de globulos blancos. Tiene un poder anticoagulant distinto en relación con su valor colorimétrico, la razón. A/C siendo de 40. Las cifras correspondientes para lì heparina de toro y el sulfato de condroitina son 100 \% 0-4 respectivamente. Su mobilidad electroforética sobrø papel de filtrar es superior a la del sulfato de condroitina su complejo con el Azul A tiene un color metacromáticœ con un máximo de absorpción a $580 \mu \mathrm{g}$. Estos datos sugieren que el A.P.S. es primeramente una substancia de tipo de heparina.

(3) El A.P.S. aislado del hígado amiloideo de un casơ de artritis reumatoide antigua se pareció al derivado de ${ }^{+}$ los glóbulos blancos. 